\title{
A promise of working through
}

\author{
[ B O O K R E VIE W ]
}

Hook, Derek (2013) (Post)apartheid

conditions: Psychoanalysis and social

formation. Basingstoke \& New York:

Palgrave Macmillan (Series: Studies in the

Psychosocial). ISBN 978-1-137-03299-7 hbk.

Pages $x+242$. (Published in 2014 by HSRC

Press. ISBN 978-07969-2458-2 pbk.

\section{Pages 252.}

I approached Hook's book with some trepidation - waiting for an appropriate build-up of energy with which to tackle his work-being familiarwith his writing and with theextent to which it has required multiple readings on my part, while never to disappoint in its depth. However, Hook's exploration of (post)apartheid conditions surprised me in its accessibility, while not compromising on the depth and complexity of his arguments. The introduction and conclusion provide a comprehensive guide for the reader and throughout the book, Hook draws on recognisable anecdotes, his own experiences and frequent summaries, that enable the reader to remain fully attentive to his more challenging articulations.

Hook embarks upon this book with two specific aims in mind: Firstly, he sets out to apply the psychosocial project to (post)apartheid South Africa; interrogating its statues, narratives of apartheid, archives of photography and nostalgic nationalisms (amongst other things) from a framework that takes seriously the psychic mechanisms at play in the social formations they represent. Secondly, he employs temporality as a central concept,

\section{Lisa Saville Young}

Department of Psychology

Rhodes University

Grahamstown 
and a neglected concept of psychosocial studies, around which the psychoanalytic interrogations of (post)apartheid society cohere.

Throughout the book, Hook employs a number of psychoanalytic concepts to interrogate the excess of social formations in (post)apartheid South Africa. These concepts include that of the uncanny and its interpellation through apartheid monuments such as those in Strijdom Square (explored in chapter 1). Hook argues that the embodied absence and disembodied presence captured in the Freudian uncanny is evoked through monuments such that "(I)t leads one to question, first, the extent to which monumental sites function precisely to recapitulate particular histories, to elicit repetition" ( $p$ 44). This reading of the uncanny in monumental markers leads, secondly, to a taking seriously of their ideological effects. This first chapter in the book could not be more relevant to institutions of higher education in South Africa, today, where monuments have become sites of assertions and conflicts.

The second chapter explores a "recurring motif of the destroyed black body" ( $p$ 48) and its intrusion into representational space. Interrogating photographs taken during apartheid, as well as more recent photos of "black-bodies-in-pieces" from the Marikana mine shooting, for example, Hook draws on Fanon and Lacan to highlight the fantasmatic qualities of these images. Weaving personal accounts of his own memories of significant images alongside key works by philosophers, social theorists and psychoanalysts, Hook deftly makes an ethical argument for the importance of owning our social fantasies and our enjoyment of them, in their obscenities, thereby hopefully making (more) conscious our own desire and less likely the need to repeat.

The third chapter on the psychology of anti-racism, and specifically, the study of whiteness, was for me the highlight of the book. Appealing for a return to Biko, and specifically for a retrieval from Biko the aspects of his work that are possibly less palatable for the progressive white liberals that employ him, Hook takes the reader through complex arguments that highlight the problems of critical whiteness studies ending with a call for the importance of Said's (2003) notion of cosmopolitanism:

"Like a wound that does not heal, cosmopolitan subjectivity is tantamount to an unsutured state, a condition of remaining painfully open, a refusal to be closed into a singular or self-enclosed entity" (Hook, 2013: 100).

Evoking Said, Hook calls for the importance of troubling whiteness studies that frequently offer foreclosed accounts representing narrative wholeness, opting instead for arguments that are fragmentary and destabilising. 
Chapters 4, 5 and 6 in the book turn to the Apartheid Archives, which aim to specifically "re-open the doors to the past ... Based on the assumption that traumatic experiences from the past will constantly attempt to re-inscribe themselves" (http://www.apartheid archive.org/site/, cited in Hook, 2013: 102). Hook begins by initially outlining a psychosocial methodological approach to the narratives in these Archives, exploring both the limitations of narrative and the importance of "ongoing symbolic activity" (p 103). Drawing on the psychoanalytic concept of "working through" Hook argues that narratives and the analysis thereof cannot aim to resolve but rather to reorganise experience, a much less idealised and altogether more modest goal. Hook goes on to demonstrate what this kind of psychosocial reading of apartheid narratives might look like offering nuanced and moving analyses of texts from the Apartheid Archive Projects. Hook's readings are excellent examples of the way in which psychosocial readings are both fine grained/inward looking in the tracking of what is said in the text as well as outward looking in the extent to which the social context is alive through the text. In addition, his overriding psychoanalytic emphasis on avoiding the obvious and searching for the surprising (i.e. what is unconscious to the text) is consistent throughout. In ending his reading of these narratives from the apartheid archives, Hook retrieves the concept of melancholia demonstrating the ways in which psychoanalytic concepts, on being employed outside of the clinical context, are frequently "tamed" thereby losing the critical edge which Freud originally inserted into society. Hook returns to the traditional psychoanalytic understanding of melancholia in order to re-claim the "resultant reflexive dynamic .... of radical self-hate which ensures that melancholia is always more than a facet of identification"(p 154). Here, Hook's extensive knowledge and understanding of classic psychoanalytic theory alongside his adeptness with more socially oriented theorists, highlights his specific contribution to the psychosocial project.

Hook's final chapter explores nostalgia as defensive formation drawing on psychoanalytic concepts such as fetishism, fantasy, screen memory and deferred action to point to some of the critical potential of nostalgia in a typical Hookian withdrawal from an easy, simplistic reading.

To summarise, Hook's book holds central the importance of affective, bodily, lived experience and resists locating this experience in the individual but rather locates it in the in-between. His emphasis on temporality echoes this emphasis as he refers to "double time" as a juxtaposition of "the past (which) might be radicalized and the future re-envisaged" ( $p$ 204). Hook's engagement with other writers from philosophy to social psychology to psychoanalysis is remarkable. The breadth of his reading and the extent to which he is able to dialogue with immanent thinkers while holding onto his own concern with the psychical investments in social formations is truly noteworthy. 
In conclusion, I believe that this book is central reading for all South Africans that are trying to navigate an ethical path through social formations that are at times both enthralling and appalling to our sensitivities. Hook offers a set of lenses and a sophisticated understanding of psychoanalytic concepts to navigate our way - leading to an altogether unsettling viewpoint that nevertheless holds the promise of working through rather than repetition. 